\title{
The Current Research Issues of Retail Internationalization
}

\author{
Miao Miao ${ }^{1}$ \\ ${ }^{1}$ Department of Contemporary Business, International Pacific University, Japan \\ Correspondence: Miao Miao, Department of Contemporary Business, International Pacific University, Japan. \\ Received: December 12, 2018 \\ Accepted: January 7, 2019 \\ Online Published: January 11, 2019 \\ doi:10.5539/ibr.v12n2p1 \\ URL: https://doi.org/10.5539/ibr.v12n2p1
}

\begin{abstract}
Retail internationalization has always attracted interest from both academics and practitioners. Although many retailers have developed international markets successfully by adopting an agile global supply chain, offline and online channels, and various store formats, some cases indicate that barriers and difficulties which retailers face when entering the foreign markets still exist. Thus, the very simple question of how to succeed in implementing retail internationalization calls for more research which investigates this question regarding different cultural contexts and industries from various perspectives. This paper is concerned with retail internationalization and the current issues affecting it. In this paper, we adopt an organizing framework to deepen the understanding of the retail internationalization process, summarize the new issues at the firm and store-level, and intend to provide a theoretical framework for further research.
\end{abstract}

Keywords: retail internationalization, current issues, capability, resource, profitability

\section{Introduction}

Retailers are playing an important role in connecting manufacturers to consumers. However, the dynamic changes such as the presence of technology and consumer's purchasing behavior are forcing retailers to come up with new strategies to respond to these challenges. For example, many retailers have created private label products by cooperating with manufacturers and have had intentions to use multiple channels to induce more opportunities to make a deep commitment with consumers. Meanwhile, the fierce competition of domestic markets reduces growth and margins of retailers, which forces retailers to move to new geographical markets (Kumar et al., 2017). That is how retail internationalization has always been a crucial issue to both academics and practitioners.

One of the reasons to consider is the big benefits of retail internationalization. Deloitte (2016) showed that 66\% of the top 250 retailers are operating in at least one foreign market. An average of $23.4 \%$ of revenues that are collected from retailers is a result of overseas operations. These retailers on average operate in 10.4 countries. These facts indicate that internationalization improves retailers' financial performance and brand awareness (Moore \& Burt, 2007).

Other crucial reasons to consider would be a firm's anxiety from entering the local market, the attractiveness of building a global network, greater economies of scale, and new opportunities for expanding an existing business (Corstjens \& Lal, 2012). Furthermore, we can see many successful examples in implementing internationalization. For instance, some fashion retailers internationalized rapidly by adopting an agile global supply chain (Brun \& Castelli, 2008), offline and online channels (Wrigley \& Currah, 2006; Premazzi et al., 2010), and various store formats (Dawson \& Mukoyama, 2014; Miao, 2017). And the fact that there are even some small and medium sized (SME) retailers that have developed international markets successfully shows that firm size is not a significant factor anymore when internationalizing (Vida et al., 2000).

However, some cases still indicate that internationalization does not have a significant impact on a retailers' returns, growth rates, or/and profit margins. This is because some barriers and difficulties exist which retailers face when entering a foreign markets, such as estate cost, rivalry among retailers; lack of experience, resources, and capabilities, regarding internationalizing (Clercq, et al., 2005; Forsgren \& Hagstrom, 2007; Alimadadi et al., 2018). Thus, how to succeed in implementing retail internationalization calls for more research in different cultural contexts and industries from various perspectives.

Previous research provided several frameworks and perspectives about retail internationalization, such as a retailer's capabilities and resources including global networks of sourcing, selling operations, and management knowledge, influence and limit the decisions of timing a firm's internationalization, entry mode, and market choice (Johnson \& Tellis 2008; Frasquet et al., 2018). In order to investigate these capabilities and resources in international expansion, some frameworks have been provided in international marketing research. For example, 
the framework of dynamic capability (Frasquet et al., 2013; Easterby-Smith \& Prieto, 2008; Winter, 2003), and embeddedness (Wood et al., 2014; Burt et al., 2015). These research frameworks offered new insight on studying the process of internationalization by looking at how retailers are gaining new capabilities for adapting to the changing environment. As Frasquet et al. (2018) presented, research should consider the role of dynamic capabilities within embedded environments, such as social, network, and territorial.

Based on these previous research, this paper is concerned with retail internationalization and the current issues affecting it. We intend to provide a theoretical framework for deepening the understanding of retail the internationalization process by adopting an organizing framework from Kumar et al. (2017).

\section{Organizing Framework}

\subsection{Retail Internationalization}

Internationalization has been defined as "the process of increasing involvement in international operations" (Welch \& Luostarinen, 1988). "The discovery, enactment, evaluation, and exploitation of opportunities - across national borders - to create future goods and services" are described as the activities that international firms are concerned with (McDougall \& Oviatt, 2000). In these activities, retail internationalization focuses on the process of providing goods or services to a new market or to a wider section of a market that already exists (Kumar et al., 2017, p.102). Most research on retail internationalization has been focusing on analyzing the entry mode, market choice, and the speed of expansion in foreign markets (Frasquet et al., 2013).

As the missions of the internationalization process, retailers need to adopt appropriate strategies and modes of foreign operation that will ensure that the business can minimize risk while maximizing the potential for success (Deloitte, 2009). The strategies are following retailers' international marketing policy, for example, underlying retail format and marketing strategy, and the goods produced or services offered by the retail (Goldman, 2001). Thus, we can see that many researchers pay attention to (1) the factors affecting the decisions of internationalization, and (2) when and how retailers should implement these strategies within international markets.

In our organizing framework (figure 1), we discuss retailers' decisions of the timing of internationalization, entry and expansion mode, market choice, and store-level strategies. All these decisions are based on retailers' capabilities and resources in implementing international marketing. Also, we intend to show the impact of these decisions on retailers' profitability at both firm and customer levels.

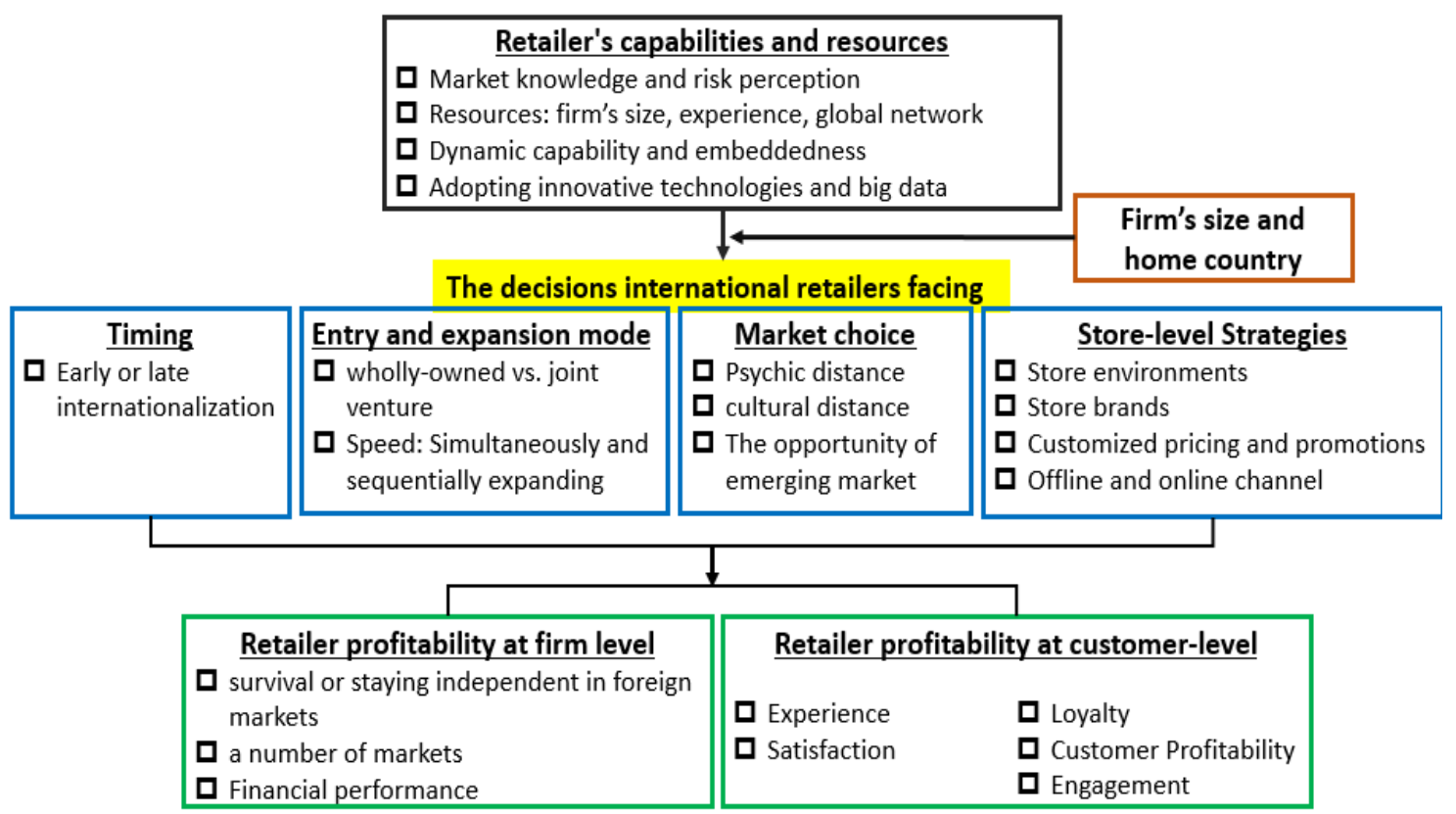

Figure 1. Organizing framework

\subsection{Impacts of Retailer's Capabilities and Resources on Internationalization Decisions}

When a retailer decides to go abroad, there are five strategic entry decisions the retailer needs to face. They are entry scale, entry mode, entry order, retail format adaptation to the local market conditions, and the familiarity of the format of the store to the parent company (Gielens \& Dekimpe, 2001). Each of these five decisions is made by considering the firm's capabilities and resources in the internationalization process (Chang \& Rhee, 2011; Jain et al., 2019). 
Researchers have highlighted several important capabilities and resources in retail internationalization from different perspectives. For example, first, the firm's level of market knowledge and risk perception limit its internationalization activities (Forsgren \& Hagstrom, 2007). This is because firms prefer to select a well-known foreign market with a similar culture and that are near the home country in order to reduce risk and uncertainty (Alimadadi et al., 2018).

Second, according to a resource-based view, resources such as firm's size, experience in internationalization, and their global network largely impact the propensity, mode, and the method of entry while entering the target foreign market (Morgan \& Katsikeas, 1997; Burt et al., 2003; Clercq et al., 2005; Javalgi et al., 2003). For instance, a lot of research in this field has focused on large firms, but not small and medium-sized firms (SMEs). This is because generally, SMEs' foreign market knowledge and resources are more limited than large firms' and thus have a more limited range of entry modes from which they can choose (Leondiou, 1995; Hutchinson et al., 2006). Furthermore, resources are also considered as part of the firm's characteristics which represent the firm's unique capabilities of entering new markets (Childs \& Jin, 2015).

Third, dynamic capability has also been considered as an important framework in internationalization studies. It has been defined as "the firm's ability to integrate, build, and reconfigure internal and external competencies to address rapidly changing environment" (Teece et al., 1997; Frasquet et al., 2013). It emphasized that firms are required to learn and develop their capabilities for making decisions at different developmental stages within environments that are fast-moving. According to Winter (2003), the competence process involves operational capabilities (zero-level), dynamic capabilities (first-order), and learning capabilities (second-order). These competency processes are related to each other. In these processes, the importance of accumulating information and learning has been outlined in different studies (Frasquet et al., 2013).

Beyond that, current research has presented some other important capabilities in the internationalization process. For example, the capability of adopting innovative technologies and big data may affect retailers' organizational routines which can influence the overall performance (Zhu \& Kraemer, 2005; Kumar et al., 2017). Bagheri et al. (2018) also examined the effective impact of technological innovation on the relationship between the activities of internationalization and performance of SME retailers. The findings suggested that retailers can improve their internationalization by implementing technological innovation activities, such as introducing new products to the market, upgrading existing products, and adopting big data to meet the market needs. Gandolfi \& Strach (2009) and Childs \& Jin (2015) also pointed out that offering functional products by adopting technological innovation can make retail be more flexible in foreign markets.

\subsection{The Impacts of Firm Size and Home Country on Internationalization}

Despite some research showing that firm size is not a significant factor in influencing international performance (Vida et al., 2000), large multinational retailer successes are well known. Additionally, only a few research paid attention to SME retailers (Hutchinson et al., 2006) - especially retailers which are in emerging countries. However, SMEs practically have great potential and capabilities in international markets with strong concepts, store formats, and merchandise assortments (Alexander \& Quinn, 2001; Hutchinson et al., 2006; Miao, 2017). Thus, instead of questioning whether or not small retailers can implement their internationalization, academic and practical researchers should investigate how small retailers could develop international marketing better in diverse industries and markets.

According to Morgan \& Katsikeas (1997) and Hutchinson et al. (2006), the variances between big and small firms are not only the physical size, such as the number of employees, stores, and annual turnover, but also in terms of managerial characteristics, financial characteristics, and operational characteristics. Compared with large firms, although the SME retailers have limited financial, operational, logistical and learning resources, they have some competitive advantages such as entrepreneurial vision and networks. For these SME retailers, Hutchinson et al. (2006) suggested that government export assistance programs could be a crucial factor for enhancing SMEs' international development effectively. It requires the government to provide support with channel relationships, network contacts, as well as information programs. This issue should be studied more in future, especially for some emerging markets like China and Africa which the export assistance program has been implemented during this decade (Jain et al., 2019).

One of the reasons is that SMEs in emerging countries have very limited governmental and political ties which encourage them to access overseas (Sharma, 2011; Deng \& Zhang, 2018). Also, the emerging markets actually internationalize more rapidly than developed markets (Deng \& Yang, 2015; Sun et al., 2012). This is because the firms in emerging markets have a higher motivation to catch-up with the established mature multinationals (Kumarasamy et al., 2012).

Crucially, most research have investigated the impact of host country and firm's capabilities and resources on the firm's internationalization process and performance, very limited studies focus on the important role of the home 
country in a firm's internationalization (Cuervo-Cazurra et al., 2018). Some current research revealed the impacts of home country's institutional changes, turbulent environment, policies on firms' decisions on internationalization (Yan et al., 2018; Fathallah et al., 2018; Barnard \& Luiz, 2018). This finding offered a direction for further research.

\section{International Marketing Decisions and the Influence Factors}

As shown in figure 1, the timing of internationalization, entry mode, market choice, and the retail store strategies are the important decisions for success in retail internationalization (Johnson \& Tellis 2008). These decisions are not only driven by firms' capabilities and resources, but also by the host country's culture, policy, local customers' preference, purchase habits, and sensitivity about new products and prices (Kumar et al., 2017).

\subsection{The Timing of Internationalization}

Some firms started internationalizing earlier in their lifecycles than other traditional, slow-paced firms. The importance of deciding when to internationalize has been addressed in previous research (Knight \& Cavusgil, 2004); however, there is not much research focusing on the antecedents of timing decision and its outcomes and implications (Jones \& Coviello, 2005; Ciravegna et al., 2018a).

One entry point of understanding the timing of internationalization is the identified perceptual and non-perceptual variables (Ciravegna et al., 2018b). The perceptible variables include perceptions of risk, size of the domestic market, and the profitability of international markets. Non-perceptual variables include the desire to exploit underutilized capacity from the resource-based view perspective and the consideration of competitors (Westhead et al., 2001). Also, a firm's background characteristics (Dimitratos, et al., 2016), such as entrepreneurial, serendipitous, and strategic internationalization were found in competing theory, which could influence the timing and type of international expansion (Ciravegna et al., 2018b; Cavusgil \& Knight, 2015).

Other drivers can be observed by looking at the challenges when retailers internationalize early, such as the limited availability of financial resources, human resources, network resources, and legitimacy (Mathews \& Zander, 2007; Bembom \& Schwens, 2018). Bembom \& Schwens (2018) emphasized three key network dimensions within the internationalization process: (1) the manner in which organizations access different types of resources, (2) an organization's utilization of governance mechanisms for the purpose of resource exchange, and (3) the diversity as well as amount of resources exchanged. Thus, we can see that resources and the capability of dealing with resources became the key points of the success of early internationalization.

Also, motives and behaviors of entrepreneurs may influence the timing in internationalization (Sommer, 2010). The correlation between innovativeness and the timing of internationalization of small retailers has been presented by Augusto \& Coelho (2009). Similarly, Efrat et al. (2017) showed that the firm with three high capabilities which include market intelligence generation, team cohesion, and marketing adaptability, might choose to internationalize early.

Although previous research have already shown different outcomes by choosing the timing to internationalize, there is still limited information about the reason of leading to different outcomes (Ciravegna et al., 2018b; Cavusgil \& Knight, 2015), and challenges from the characteristics of industry and product categories (Ciravegna et al., 2018a).

\subsection{Entry Mode Choice}

Entry mode choice is considered as foreign operation mode (FOM) -- "the organizational arrangement that a company uses to conduct international business activities" (Picot-Coupey et al., 2014; Benito et al., 2009, p.1458). FOM was categorized into wholly-owned operation (flagship stores), and joint venture (shop-in-shops, franchised stores). The mode of entry that is wholly owned has a higher level involvement/control and gains more returns compared to franchise, while franchise carries lower investment cost (Ekeledo \& Sivakumar, 1998).

Based on the eclectic framework, Nakos \& Brouthers (2002) examined the factors influencing entry mode, which are ownership, internalization, and pioneering advantage. From the resource-based view, Park \& Sternquist (2008) presented the impact of resource availability on retailer's entry mode choice. Thus, we can see that the characteristics of retailers' resource, advantages, and capabilities might lead to different choice of entry mode. For example, retailers with a unique capability and competitive advantage in the management or production of private label products prefer wholly-owned entry mode. On the other hand, the retailers who have abundant access to relational resources but do not have informational, managerial or capital resources will opt to utilize franchise mode (Park \& Sternquist, 2008).

Additionally, some research have presented the different entry modes by classifying internationalization speed that engages in international expansion simultaneously or entry to new markets in a short period (Birchall, 2008; Dawson \& Mukoyama, 2014; Mohr \& Batsakis, 2014). For example, based on resource-based view, Mohr \& Batsakis (2018) compared simultaneously and sequentially expanding retailers, and presented that if the firm is 
able to (1) draw on assets that are intangible, (2) be strong financially, as well as (3) have gained international experience, it has the intension to get involved in simultaneous international expansion.

Furthermore, Picot-Coupey et al. (2014) emphasized the difference between retailers' entry and expansion modes. It suggests a dynamic perspective to look at FOM as a distinct stage within the internationalization process. At the different stages, there are different factors related to the characteristics of the organization and environmental characteristics that determine the appropriate choice of FOM.

\subsection{Market Choice}

Which counties are being selected, and what factors can explain the choice of market, have been investigated in some research. The factors leading retailers to make a choice of market were considered to be the country's economic situation (Dunning, 2000), the purchasing power (Alexander, 1990), the size of the market (Mitra \& Golder, 2002), and distance between home market and selected market (Evans \& Mavondo, 2002). These research provided foundational factors that could influence retailers' decisions on market choice.

Especially, current research has been focused on the impact of distance between home and host markets including geographic and psychic distance. Alexander et al. (2007) and Evans \& Mavondo (2002) emphasized that psychic distance may produce more difference in financial results. The reason is that if a firm chose to enter a market with high perceived differences to the firm's home market, the firm would take a lot of effort and time to understand the market which might lead to improved financial performance. Also, Mohr \& Batsakis (2018) found a restraining effect of cultural distance in regard to the relationship between retailers' international experience and their simultaneous international expansion.

Furthermore, some case studies showed that firms offering products which are more connected to home country may receive higher risks if they entered psychical distant markets (Gandolfi \& Strach, 2009; Burt, et al., 2003). It means that product category offering can influence the performance of market choice.

On the other hand, through an assessment of the emerging market criteria - the potential of the market, culture distance, the industry competitive strength, and the receptiveness of the customer, Sakarya, et al. (2007) addressed the growth and potential opportunities in emerging markets. This finding pointed the attractiveness of emerging markets for both retailers' internationalization and academic research.

\subsection{Store-level Strategies}

In order to offer the consumer a superior shopping experience, international retailers came to pay more attention to their store-level strategies which include store environment, assortment of merchandise, customized pricing and promotions, and offline and online channel building. The reason is that store environment and atmosphere can stimulate consumers' emotional states (i.e., pleasure, fun, and arousal) which can create an emotional relationship between the consumer and the store, while merchandise, pricing and promotions can create a rational relationship (Kumer \& Kim, 2014). Thus, we can see that retail internationalization is paying more attention to holistic marketing management which not only concerns product development, but also inventive store formats and interaction of multiple channels such as offline and online channels.

First, many retailers have recently been building a greater variety of store formats in foreign markets and attempting to provide a superior shopping experience through their store environment in order to increase the possibility of customer revisitation and store performance (Kumar \& Kim, 2014; Garaus et al., 2015; Murray et al., 2017). The reason is that consumers not only switch to different retailers in the same product categories but also change to different store formats for the same product purchasing (Anand \& Sinha, 2009). In other words, store environment with different formats can influence store image and customers' store choice differently (Fowler \& Bridges, 2010). There is already much research showing the impact of store environment on customer's satisfaction and loyalty (Kumar \& Kim, 2014; Garaus et al., 2015); and international expansion as well as adapting merchandise, customized pricing and promotions to the local market (Broyles, 2009).

Second, the development of e-commerce offers store-based retailers a high possibility of extending their business to foreign countries (Wrigley \& Currah, 2006; Premazzi et al., 2010). It can be observed in the great attention from academic literature and industry practice on the synergies across the online and offline business (Zhang et al., 2010). For example, operating both online and offline stores can (1) reach foreign markets with low cost (Premazzi et al., 2010); (2) grow the number of customers (Kushwaha \& Shankar, 2013); (3) enhance customer gratification and loyalty towards the existing stores (Neslin \& Shankar, 2009); (4) increase sales revenues (Pauwels \& Neslin, 2015). Although some research also questioned the synergy between online and offline retailing and the contributions to retailers' internationalization (Van Nierop et al., 2011), adopting both offline and online stores is still being given great attention by international retailers.

\section{Retailer Profitability at Firm and Customer-Level}

For measuring the outcomes of firms' internationalization, most research adopted firm-level's profit and other 
financial performance data. The most common measures are traditional accounting-based ratios such as return on investment (ROI), return on equity (ROE), profit margin, return on assets (ROA) (Calabrese \& Manello, 2018; Majocchi \& Zucchella, 2003; Calabrese \& Erbetta, 2005) or other direct measures such as market share and sales growth (Arvanitis \& Loukis, 2012; Manello et al., 2016). Similarly, survival which is measured by the number of markets, the ownership changes, or expansion using the same mode was presented by Ciravegna et al. (2018a).

Although these financial statements directly show the profitability at firm-level, it also requires to adopt other indirect measurements to evaluate profitability at customer-level, such as customer satisfaction, loyalty, and brand reputation. This is why the customer-level perspective offers customer-focused marketing and brings long-term profitability (Kumar et al., 2017). Also, consumers are becoming more diverse and complicated even within one country because of the indigenous cultural values of different areas (De Mooij, 2010). Thus, to look at the profitability at customer-level should be helpful for retailers to improve their retailing activities in host markets. Retailers' profitability at customer-level can be represented with experience, satisfaction, loyalty, profitability, and engagement which all connects to each other (Kumar et al., 2017). When a customer has a good experience within the whole purchase process, it will lead to their satisfaction which can produce customer loyalty and sustained profitability, and then deepen customer's engagement towards this store or product.

In these measurements, especially the linkage of satisfaction and loyalty has been focused by researchers and market managers in the last 20 years. Satisfaction refers to the consumer's sense that the consumption successfully satisfies specific, desire, need, goal, and also provides outcomes against a pleasure standard. Much research has examined that satisfaction is a strong relative factor of loyalty (Jones et al., 2000; Szymanski \& Henard, 2001; Anderson \& Srinivasan, 2003). Additionally, cultivating and retaining customer loyalty is an important task for almost all companies in any business. This is because loyal customers can give more business and benefits and it costs less to a company to serve them.

Despite satisfaction-loyalty linkage being studied by many researchers, the topic of how to best allocate resources to various loyalty-building efforts has always attracted interest from both academics and practitioners. We can see some international retailers have recently been attempting to provide a superior shopping experience through their store environment and multiple channels in order to increase the possibility of customer revisitation and customer loyalty. For example, some retailers are building a greater variety of store formats (Miao, 2017); store-based retailers tend to participate in e-commerce (Gensler et al., 2007).

Notably, some research posit that not all loyal customers bring profit to the firm, and provide recommendation that it is essential for customers be categorized based on loyalty as well as profitability (Kumar et al., 2017; Reinartz \& Kumar, 2002; Kotler \& Keller, 2016). Miotto \& Parente (2015) suggested that different store formats should be used to attract different types of consumers based on profitability. However, this issue requires retailers to share information about customers and make a strategy to target profitable customers (Kumar et al., 2017). This field of research needs to be developed by investigating diverse industries and markets in the future.

\section{Current Issues of Internationalization}

This study contributes to research in the retail internationalization field by providing a comprehensive framework that will assist researchers gain an understanding of the research topic being studied and focused in previous research, and the current issues which should be paid more attention in the future. The proposed framework in this paper focuses on retailer's profitability at both firm and customer-level and identifies the types of decisions of internationalization being based on retailer's capabilities and resources. We choose to focus on four current issues covering firm and store levels, which are about research method, dynamic perspective, SME retailers' internationalization, and the new retail formats and channel expansion (Figure 2). 


\begin{tabular}{|c|c|}
\hline 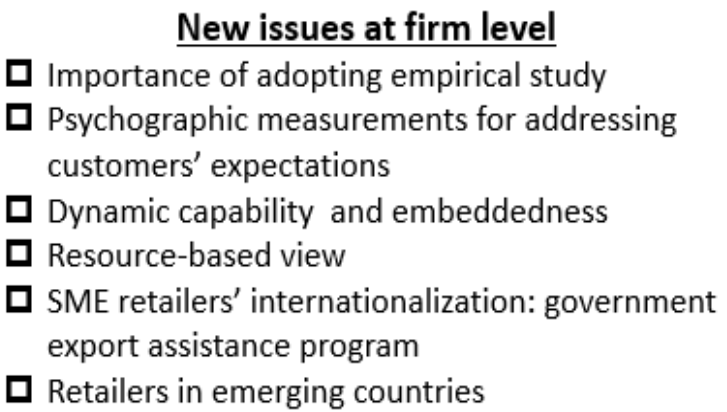 & $\begin{array}{l}\quad \text { New issues at Store-level } \\
\text { New retail formats and channel expansion } \\
\text { Improve experience at touchpoint } \\
\square \text { New product lines and localized pricing } \\
\text { strategy } \\
\square \text { Online shopping and mobile technology } \\
\text { utilization }\end{array}$ \\
\hline $\begin{array}{l}\text { The combination of case study and empirical res } \\
\text { The impact of firm characteristics with dynamic } \\
\text { T New store formats and channel expansion } \\
\text { SME retailers' internationalization in emerging } \\
\mathbf{\square} \text { impact of home country institutions and charac }\end{array}$ & $\begin{array}{l}\text { arch } \\
\mathrm{h} \text { on internationalization } \\
\text { pective } \\
\text { ries } \\
\text { tics on the strategy of the firm }\end{array}$ \\
\hline
\end{tabular}

Figure 2. Current issues

\subsection{Research Method: Combination of Case Study and Empirical Investigation}

Most research adopt case studies to show the process of retail internationalization, but lacks an empirical investigation with theoretical support (Childs \& Jin, 2015). Although case study can help researchers and firms to understand the specific barriers of entering a foreign market and the crucial capabilities supporting firms to develop the market (Frasquet et al., 2013; Dawson \& Mukoyama, 2014), it still requires researchers to combine case study and empirical investigation to find out the correlations between international market decisions and outcomes.

There are several methods and frameworks which were suggested to measure firms' outcomes, for example, at firm-level evaluation of FOM characteristics can minimize the risk and understand the level of resource commitment in regard to firm's plan on international marketing (Picot-Coupey et al., 2014). SOR (Stimuli-Organism-Response) paradigm can find out the factors influencing customer's emotional states and response (Mehrabian \& Russell, 1974; Laroche \& Park, 2013). Measuring customer loyalty and engagement can show the relationship between customer and a retail store/brand (Jones et al., 2000; Szymanski \& Henard, 2001; Anderson \& Srinivasan, 2003). Also, psychographic measurements show customers' expectations, customer demographics, and lifestyles which can provide a hint to international retailers (Ko et al., 2012).

These measurements can show a firm's performance and customers' response towards retailing activities at each different touch point in the internationalization process. It helps retailers to better understand what they do indeed need to work on and how to address customers' expectations appropriately at different developing stages (Kumar et al., 2017).

\subsection{The Impact of Firm Characteristics with Dynamic Perspective}

Paying attention to firm characteristics including capabilities and resources from dynamic perspective will be a key to understand a firm's decisions on internationalization (Moore \& Burt, 2007; Childs \& Jin, 2015). These unique characteristics are based on firm's experiences, developing history, resources, knowledge, and learning capabilities which could be developed by the firm's activities in the changing environment. Recently, we can see two main frameworks showing the importance of dynamic perspective in internationalization. They are dynamic capability (Winter, 2003; Frasquet et al., 2013; Easterby-Smith \& Prieto, 2008), and embeddedness (Wood et al., 2014; Burt et al., 2015; Frasquet et al., 2018; Kinoshita, 2018). These research offered a new insight to study the process of internationalization by considering the role of dynamic capabilities within the embedded environment (social structure, network and territorial).

In addition to this, the resource-based view has been contributing to international marketing research. Some research showed that the entry mode could be related to the possession of intangible assets by the retailers, such as selling operations and management knowledge, learning ability, global networks of sourcing, as well as their international experience (Frasquet et al., 2018; Mohr \& Batsakis, 2018). These resources were considered to be able to offer (1) a strong retail brand expanded across borders with high speed (Swoboda et al., 2014); (2) ability to deal with particular challenges from new markets and adjust to local needs (Jiang et al., 2014; Bianchi \& 
Ostale, 2006). The resource-based view deepens the understanding of the impacts of retailer's capabilities and resources on internationalization.

Besides, because firms need time to configure their resources to achieve their financial goals after entering a new market, researchers should consider the effect of time-series as evaluating the impacts of firm's capabilities and resources on international performance (Sun et al., 2018).

\subsection{SME Retailer's Internationalization in the Emerging Counties}

Although some research showed that firm size is not a significant factor influencing internationalization (Vida et al., 2000), the difficulties and characteristics of developing internationalization of SME retailers are different with large firms.

Compared with large retailers, the SME retailers have limited, operational, logistical, and financial as well as learning resources. But, they also have some competitive advantages, such as entrepreneurial vision and networks (Hutchinson et al., 2006). Some studies presented that SME retailers have great potential and capabilities in international markets with strong concepts, inventive store formats and merchandise assortment (Alexander \& Quinn, 2002; Hutchinson et al., 2006; Miao, 2017).

As an application, Hutchinson et al. (2006) suggested that government export assistance programs are an important factor in enhancing SME retailer's international development. It requires the government to offer assistance with channel relationships, network contacts as well as information programs related to international issues.

In addition to this, only a few research paid attention to international retailers in emerging countries. Deng \& Zhang (2018) addressed that institutional quality (business administration, trade regulation, tax administration, labor regulation, etc) is related to the decision of whether the Chinese SMEs intend to go overseas and their overseas sales growth. It is shown that the Chinese SMEs who have very limited governmental and political ties would choose to access overseas. Also, some other research explained that firms in emerging economies with low institutional quality can easily produce efficient business operations (Sharma, 2011; Deng \& Zhang, 2018). It means that the home country's institutional changes, business environment and policies have a significant effect on retailers' internationalization (Cuervo-Cazurra et al., 2018; Yan et al., 2018; Fathallah et al., 2018; Barnard \& Luiz, 2018). Thus, as Jain et al. (2019) addressed, the influence factors of internationalization could be different between developed and emerging markets. For this field, it calls for further studies.

\subsection{New Retail Formats and Channel Expansion}

At store-level, Kumar et al. (2017) suggested that further research should focused on (1) the impacts of new retail store formats on internationalization; (2) the effect of market expansion through new product lines and localized pricing strategy; (3) retail channel expansion such as the combination of e-commerce and physical retail store.

Especially, for (1), only a few research pays attention to the issue of how, and to what extent, the different store formats impact customer satisfaction and loyalty building. This is especially true of retailers entering a new overseas market, and how its store format choice affects its loyalty building during its developing stages.

For the (3), the main purpose of building multichannel is to simply communicate with customers for targeting potential benefits (Zhang et al., 2010). This has been applicable to a wide range of industries by store-based, catalog, television shopping, and internet-based retailers in the last 20 years (Neslin et al., 2006). Specifically, the development of virtual technologies and e-commerce offers two main opportunities to store-based retailers, the possibility of offering value efficiently to customers through both online and offline retailing, and extending their business to foreign countries (Wrigley \& Currah, 2006; Premazzi et al., 2010). Now, the combination of offline and online channel came to be more important than before. Especially when more customers purchasing through their smartphones, further researchers should pay more attention to test the effects of building up cross-channel (online and offline shop) and mobile technology utilization on both business performance and retailing internationalization.

Today, retailers who operate in the multinational arena have become robust with their holistic marketing plans that are focused on the development of private label products and reinforcement of brand value through the use of inventive store formats and multiple retail channels (Miao, 2017). We can see this in the success of the great grocery stores (Walmart, Whole Foods), apparel merchants (GAP, H\&M, ZARA), online shopping websites (Amazon, etc.). A lot of research has been conducted with an aim of investigating international marketing innovation within retail. However, as we addressed in this paper, there are still some questions, such as when and how retailers start to internationalize, that are major factors that might influence their internationalization process and what strategies they could implement as they experience barriers and difficulties. 
The proposed framework in this study intends to reorganize the important views and frameworks in previous research about retail internationalization, as well as identify several directions and implications for further research. However, we could not summarize all the important topics and discussions, such as the role of information sharing in a firm's internationalization (Kumar et al., 2017), comparison of international performance among multiple markets (Childs \& Jin, 2015), and tradeoffs between strategic localization and standardization (Knight \& Cavusgil, 2004). These issues also require attention in the future.

\section{References}

Alexander, N. (1990). Retailers and international markets: Motives for expansion. International Marketing Review, 7(4), 75-85. https://doi.org/10.1108/02651339010142797

Alexander, N., \& Quinn, B. (2002). International retail divestment. International Journal of Retail \& Distribution Management, 30(2), 112-125. https://doi.org/10.1108/09590550210418137

Alexander, N., Rhodes, M., \& Myers, H. (2007). International market selection: Measuring actions instead of intentions. Journal of Services Marketing, 21(6), 424-434. https://doi.org/10.1108/088760407 10818912

Alimadadi, S., Bengtson, A., \& Hadjikhani, A. (2018). How does uncertainty impact opportunity development in internationalization? International Business Review, 27, 161-172. https://doi.org/10.1016/j.ibusrev.2017.06.002

Anand, K. S., \& Sinha, P. K. (2009). Store format choice in an evolving market: Role of affect, cognition and involvement. The International Review of Retail, Distribution and Consumer Research, 19(5), 505-534. https://doi.org/10.1080/09593960903445376

Anderson, R. E., \& Srinivasan, S. S. (2003). E-satisfaction and e-loyalty: A contingency framework. Psychology \& Marketing, 20(2), 123-138. https://doi.org/10.1002/mar.10063

Arvanitis, S., \& Loukis, E. N. (2012). Outsourcing and firm performance -A comparative study of Swiss and Greek firms. Industrial and Corporate Change, 22(3), 771-806. https://doi.org/10.1093/icc/dts032

Augusto, M., \& Coelho, F. (2009). Market orientation and new-to-the-world products: Exploring the moderating effects of innovativeness, competitive strength, and environmental forces. Industrial Marketing Management, 38(1), 94-108. https://doi.org/10.1016/j.indmarman.2007.09.007

Bagheri, M., Mitchelmore, S., Bamiatzi, V., \& Nikolopoulos, K. (2018). Internationalization Orientation in SMEs: The mediating role of technological innovation. Journal of International Management. https://doi.org/10.1016/j.intman.2018.08.002

Barnard, H., \& Luiz, J.M. (2018). Escape FDI and the dynamics of a cumulative process of institutional misalignment and contestation: Stress, strain and failure. Journal of World Business, 53(5), 605-619. https://doi.org/10.1016/j.jwb.2018.03.010

Bembom, M., \& Schwens, C. (2018). The role of networks in early internationalizing firms: A systematic review and future research agenda. European Management Journal. https://doi.org/10.1016/j.emj.2018.03.003

Benito, G., Petersen, B., \& Welch, L. S. (2009). Towards more realistic conceptualisations of foreign operation modes. Journal of International Business Studies, 40(9), 1455-1470. https://doi.org/10.1057/jibs.2009.54

Bianchi, C. C., \& Ostale, E. (2006). Lessons learned from unsuccessful internationalization attempts: Examples of multinational retailers in Chile. Journal of Business Research, 59(1), 140-147. https://doi.org/10.1016/j.jbusres.2005.01.002

Birchall, J. (2008). Best Buy plots its global strategy. Financial Times, May 13, https://www.ft.com/content/d4904892-206b-11dd-80b4-000077b07658

Brun, A., \& Castelli, C. (2008). Supply chain strategy in the fashion industry: Developing a portfolio model depending on product, retail channel and brand. International Journal of Production Economics, 116(2), 169-181. https://doi.org/10.1016/j.ijpe.2008.09.011

Burt, S., Dawson, J., \& Sparks, L. (2003). Failure in international retailing: research propositions. The International Review of Retail, Distribution and Consumer Research, 14(4), 355-373. https://doi.org/10.1080/0959396032000129471

Burt, S., Johansson, U., \& Dawson, J. (2015). International retailing as embedded business models. Journal of Economic Geography, 16, 715-747. https://doi.org/10.1093/jeg/lbv008

Calabrese, G. G., \& Erbetta, F. (2005). Outsourcing and firm performance: Evidence from Italian automotive suppliers. International Journal of Automotive Technology and Management, 5(4), 461-479. https://doi.org/10.1504/IJATM.2005.008585 
Calabrese, G. G., \& Manello, A. (2018). Firm internationalization and performance: Evidence for designing policies. Journal of Policy Modeling, 40, 1221-1242. https://doi.org/10.1016/j.jpolmod.2018.01.008

Cavusgil, S. T., \& Knight, G. (2015). The born global firm: An entrepreneurial and capabilities perspective on early and rapid internationalization. Journal of International Business Studies, 46(1), 3-16. https://doi.org/10.1057/jibs.2014.62

Chang, S. J., \& Rhee, J. (2011). Rapid FDI expansion and firm performance. Journal of International Business Studies, 42, 979-994. https://doi.org/10.1057/jibs.2011.30

Childs, M. L., \& Jin, B. (2015). Firm factors that influence internationalisation and subsequent financial performance of fashion retailers. Journal of Service Theory and Practice, 25(1), 95-114. https://doi.org/10.1108/JSTP-09-2013-0204

Ciravegna, L., Kuivalainen, L., Kundu, S. K., \& Lopez, L. E. (2018a). The antecedents of early internationalization: A configurational perspective. International Business Review, 27, 1200-1212. https://doi.org/10.1016/j.ibusrev.2018.05.002

Ciravegna, L., Kundu, S. K., Kuivalainen, O., \& Lopez, L. E. (2018b). The timing of internationalization Drivers and outcomes. Journal of Business Research. https://doi.org/10.1016/j.jbusres.2018.08.006.

Clercq, D. D., Sapienza, H. J., \& Crijns, H. (2005). The internationalization of small and medium sized firms. Small Business Economics, 24(4), 409-419. https://doi.org/10.1007/s11187-005-5333-X

Corstjens, M., \& Lal, R. (2012). Retail doesn't cross borders: Here's why and what to do about it. Harvard Business Review, 90(4), 104-111. https://www.hbs.edu/faculty/Pages/item.aspx?num=42423

Cuervo-Cazurra, A., Luo, Y., Ramamurti, R., \& Ang, S. H. (2018). The Impact of the home country on internationalization. Journal of World Business, 53, https://doi.org/10.1016/S0022-4359(01)00044-6

Dawson, J., \& Mukoyama, M. (2014). Recent developments in retail internationalization. Dawson, \& M. Mukoyama (Eds.), Global strategies in retailing: Asian and European experiences (5-36). London: Routledge.

De Mooij, M. (2010). Consumer behavior and culture: Consequences for global marketing and advertising. Sage Publications.

Deloitte (2009). Global Powers of Retailing 2009. https://public.deloitte.com/media/0460/2009GlobalPowersofRetail_FINAL2.pdf

Deloitte (2016). Global Powers of Retailing 2016. https://www2.deloitte.com/content/dam/ Deloitte/global/Documents/Consumer-Business/gx-cb-global-powers-of-retailing-2016.pdf

Deng, P., \& Yang, M. (2015). Cross-border mergers and acquisitions by emerging market firms: A comparative investigation. International Business Review, 24(1), 157-172. https://doi.org/10.1016/j.ibusrev.2014.07.005

Deng, P., \& Zhang, S. (2018). Institutional quality and internationalization of emerging market firms: Focusing on Chinese SMEs. Journal of Business Research, 92, 279-289. https://doi.org/10.1016/j.jbusres.2018.07.014

Dimitratos, P., Johnson, J. E., Plakoyiannaki, E., \& Young, S. (2016). SME internationalization: How does the opportunity-based international entrepreneurial culture matter? International Business Review, 25(6), 1211-1222. https://doi.org/10.1016/j.ibusrev.2016.03.006

Dunning, J. H. (2000). The eclectic paradigm as an envelope for economic and business theories of MNE activity. International Business Review, 9(2), 163-190. https://doi.org/10.1016/S0969-5931(99)00035-9

Easterby-Smith, M., \& Prieto, I. M. (2008). Dynamic capability and knowledge management: An integrative role for learning?. British Journal of Management, 19, 235-249. https://doi.org/10.1111/j.1467-8551.2007.00543.x

Efrat, K., Gilboa, S., \& Yonatany, M. (2017). When marketing and innovation interact: The case of born-global firms. International Business Review, 26, 380-390. https://doi.org/10.1016/j.ibusrev.2016.09.006

Ekeledo, I., \& Sivakumar, K. (1998). Foreign market entry mode choice of service firms: A contingency perspective. Journal of the Academy of Marketing Science, 26(4), 274-292. https://doi.org/10.1177/0092070398264002

Evans, J., \& Mavondo, F. T. (2002). Psychic distance and organizational performance: An empirical investigation of international retailing operations. Journal of International Business Studies, 33(3), 515-532. https://doi.org/10.1057/palgrave.jibs.8491029 
Fathallah, R., Branzei, O., \& Schaan, J. L. (2018). No place like home? How EMNCs from hyper turbulent contexts internationalize by sequentially arbitraging rents, values, and scales abroad. Journal of World Business, 53(5), 620-631. https://doi.org/10.1016/j.jwb.2018.04.001

Forsgren, M., \& Hagström, P. (2007). Ignorant and impatient internationalization? The Uppsala model and internationalization patterns for internet-related firms. Critical Perspectives on International Business, 3(3), 291-304. https://doi.org/10.1108/17422040710832559

Fowler, K., \& Bridges, E. (2010). Consumer innovativeness: Impact on expectations, perceptions, and choice among retail formats. Journal of Retailing and Consumer Services, 17(6), 492-500. https://doi.org/10.1016/j.jretconser.2010.08.004

Frasquet, M., Dawson, J., \& Molla, A. (2013). Post-entry internationalisation activity of retailers. Management Decision, 51(7), 1510-1527. https://doi.org/10.1108/MD-02-2013-0081

Frasquet, M., Dawson, J., Calderon, H., \& Fayos, T. (2018). Integrating embeddedness with dynamic capabilities in the internationalisation of fashion retailers. International Business Review, 27, 904-914. https://doi.org/10.1016/j.ibusrev.2018.02.002

Gandolfi, F., \& Strach, P. (2009). Retail internationalization: Gaining insights from the Wal-Mart experience in South Korea. Review of International Comparative Management, 10(1), 187-199. http://rmci.ase.ro/ro/no10vol1/Vol10_No1_Article17.pdf

Garaus, M., Wagner, U., \& Kummer, C. (2015). Cognitive fit, retail shopper confusion, and shopping value: An empirical investigation. Journal of Business Research, 68(5), 1003-1011. https://doi.org/10.1016/j.jbusres.2014.10.002

Gensler, S., Marnik, G. D., \& Bernd, S. (2007). Evaluating channel performance in multi-channel environments. Journal of Retailing and Consumer Services, 14(1), 17-23. https://doi.org/10.1016/j.jretconser.2006.02.001

Gielens, K., \& Dekimpe, M. G. (2001). Do international entry decisions of retail chains matter in the long run? International Journal of Research in Marketing, 18(3), 235-259. https://doi.org/10.1016/S0167-8116(01)00039-8

Goldman, A. (2001). The transfer of retail formats into developing economies: The example of China. Journal of Retailing, 77(2), 221-242. https://doi.org/10.1016/S0022-4359(01)00044-6

Hutchinson, K., Quinn, B., \& Alexander, N. (2006). SME retailer internationalisation: Case study evidence from British retailers. International Marketing Review, 23(1), 25-53. https://doi.org/10.1108/02651330610646287

Jain, N. K., Celo, S., \& Kumar V. (2019). Internationalization speed, resources and performance: Evidence from Indian software industry. Journal of Business Research, 95, 26-37. https://doi.org/10.1016/j.jbusres.2018.09.019

Javalgi, R. G., Griffith, D. A., \& White, D. S. (2003). An empirical examination of factors influencing the internationalization of service firms. Journal of Services Marketing, 17(2), 185-201. https://doi.org/10.1108/08876040310467934

Jiang, R. J., Beamish, P. W., \& Makino, S. (2014). Time compression diseconomies in foreign expansion. Journal of World Business, 49(1), 114-121. https://doi.org/10.1016/j.jwb.2013.02.003

Johnson, J. K., \& Tellis, G. J. (2008). Drivers of success for market entry into China and India. Journal of Marketing, 72(3), 1-13. https://doi.org/10.1509/jmkg.72.3.1

Jones, M. A., Mothersbaugh, D. L., \& Beatty, S. E. (2000). Switching barriers and repurchase intentions in services. Journal of Retailing, 76(2), 259-74. https://doi.org/10.1016/S0022-4359(00)00024-5

Jones, M. V., \& Coviello, N. E. (2005). Internationalisation: Conceptualising an entrepreneurial process of behaviour in time. Journal of International Business Studies, 36(3), 284-303. https://doi.org/10.1057/palgrave.jibs.8400138

Kinoshita, A. (2018). How is a retail business brand embedded in social structure, networks, and territories? A historical case of Uniqlo. The Journal of Japan Society for Distribution Sciences, 41, 1-18. https://ci.nii.ac.jp/naid/40021499256/

Knight, G. A., \& Cavusgil, S. T. (2004). Innovation, organizational capabilities, and the born-global firm. Journal of International Business Studies, 35(2), 124-141. https://doi.org/10.1057/palgrave.jibs.8400071

Ko, E., Taylor, C. R., Sung, H., Lee, J., Wagner, U., Navarro, D. M. C., \& Wang, F. (2012). Global marketing segmentation usefulness in the sportswear industry. Journal of Business Research, 65, 1565-1575. https://doi.org/10.1016/j.jbusres.2011.02.041 
Kotler, P., \& Keller, K. L. (2016). A framework for marketing management, Sixth edition, Pearson.

Kumar, A., \& Kim, Y. K. (2014). The store-as-a-brand strategy: the effect of store environment on customer responses. Journal of Retailing and Consumer Services, 21, 685-695. https://doi.org/10.1016/j.jretconser.2014.04.008

Kumar, V., Anand, A., \& Song, H. (2017). Future of Retailer Profitability: An Organizing Framework. Journal of Retailing, 93(1), 96-119. https://doi.org/10.1016/j.jretai.2016.11.003

Kumarasamy, A., Mudambi, R., Saranga, H., \& Tripathy, A. (2012). Catch-up strategies in the Indian auto components industry: Domestic firms' response to market liberalization. Journal of International Business Studies, 43(4), 368-395. https://doi.org/10.1057/jibs.2012.4

Kushwaha, T., \& Shankar, V. (2013). Are multichannel customers really more valuable? The moderating role of product category characteristics. Journal of Marketing, 77(4), 67-85. https://doi.org/10.1509/jm.11.0297

Laroche, M., \& Park, S. Y. (2013). Recent advances in globalization, culture and marketing strategy: Introduction to the special issue. Journal of Business Research, 66, 955-957. https://doi.org/10.1016/j.jbusres.2011.12.017

Leondiou, L. C. (1995). Export stimulation research: review, evaluation and integration. International Business Review, 4, 133-156. https://doi.org/10.1016/0969-5931(95)00002-H

Majocchi, A., \& Zucchella, A. (2003). Internationalization and performance findings from a set of Italian SMEs. International Small Business Journal, 21(3), 249-268. https://doi.org/10.1177\%2F02662426030213001

Manello, A., Calabrese, G., \& Frigero, P. (2016). Technical efficiency and productivity growth along the automotive value chain: Evidence from Italy. Industrial and Corporate Change, 25(2), 245-259. https://doi.org/10.1093/icc/dtv021

Mathews, J. A., \& Zander, I. (2007). The international entrepreneurial dynamics of accelerated internationalization. Journal of International Business Studies, 38(3), 387-403. https://doi.org/10.1057/palgrave.jibs.8400271

McDougall, P. P., \& Oviatt, B. M. (2000). International Entrepreneurship: The Intersection of Two Research Paths. The Academy of Management Journal, 43(5), 902-906. http://dx.doi.org/10.5465/1556418

Mehrabian, A., \& Russell, J. A. (1974). The basic emotional impact of environments. Perceptual and Motor Skills, 38, 283-301. https://doi.org/10.2466\%2Fpms.1974.38.1.283

Miao, M. (2017). The Process of Retail Internationalization in the Chinese Market: A Case of Japanese Fashion Company. International Journal of Marketing Studies, 9(5), 95-107. https://doi.org/10.5539/ijms.v9n5p95

Miotto, A. P., \& Parente, J. G. (2015). Retail evolution model in emerging markets: Apparel store formats in Brazil. International Journal of Retail \& Distribution Management, 43(3), 242-260. https://doi.org/10.1108/IJRDM-03-2012-0025

Mitra, D., \& Golder, P. N. (2002). Whose culture matters? Near-market knowledge and its impact on foreign market entry. Journal of Marketing Research, 39(3), 350-365. https://doi.org/10.1509/jmkr.39.3.350.19112

Mohr, A., \& Batsakis, G. (2014). Intangible assets, international experience and the internationalization speed of retailers. International Marketing Review, 31(6), 601-620. https://doi.org/10.1108/IMR-09-2013-0186

Mohr, A., \& Batsakis, G. (2018). Firm resources, cultural distance and simultaneous international expansion in the retail sector. International Business Review, 27, 113-124. https://doi.org/10.1016/j.ibusrev.2017.05.010

Moore, C. M., \& Burt, S. (2007). Developing a research agenda for the internationalisation of fashion retailing. Hines, T. \& Bruce, M. (Eds), Fashion Marketing: Contemporary Issues, Elsevier, Burlington, MA, 48-65.

Morgan, R. E., \& Katsikeas, C. S. (1997). Export stimuli: Export intention compared with export activity. International Business Review, 6, 477-499. https://doi.org/10.1016/S0969-5931(97)00017 -6

Murray, J., Elms, J., \& Teller, C. (2017). Examining the role of store design on consumers' cross sectional perceptions of retail brand loyalty. Journal of Retailing and Consumer Services, 38, 147-156. https://doi.org/10.1016/j.jretconser.2017.06.001

Nakos, G., \& Brouthers, K. D. (2002). Entry mode choice of SMEs in Central and Eastern Europe. Entrepreneurship Theory \& Practice, 27(1), 47-63. https://doi.org/10.1111/1540-8520.271003

Neslin, S. A., \& Shankar, V. (2009). Key issues in multichannel customer management: Current knowledge and future directions. Journal of Interactive Marketing, 23(1), 70-81. https://doi.org/10.1016/j.intmar.2008.10.005

Neslin, S. A., Grewal, D., Leghorn, R., Shankar, V., Teerling, M. L., Thomas, J. S., \& Verhoef, P. C. (2006). 
Challenges and opportunities in multichannel customer management. Journal of Service Research, 9(2), 95-112. https://doi.org/10.1177/1094670506293559

Park, Y., \& Sternquist, B. (2008). The global retailer's strategic proposition and choice of entry mode. International Journal of Retail \& Distribution Management, 36(4), 281-299. https://doi.org/10.1108/09590550810862688

Pauwels, K., \& Neslin, S. A. (2015). Building with bricks and mortar: The revenue impact of opening physical stores in a multichannel environment. Journal of Retailing, 91(2), 182-197. https://doi.org/10.1016/j.jretai.2015.02.001

Picot-Coupey, K., Burt, S., \& Cliquet, G. (2014). Retailers' expansion mode choice in foreign markets: Antecedents for expansion mode choice in the light of internationalization theories. Journal of Retailing and Consumer Services, 21, 976-991. https://doi.org/10.1016/j.jretconser.2014.08.018

Premazzi, K., Castaldo, S., Grosso, M., \& Hofacher, C. (2010). Supporting retailers to exploit online settings for internationalization: The different role of trust and compensation. Journal of Retailing and Consumer Services, 17(3), 229-240. https://doi.org/10.1016/j.jretconser.2010.03.006

Reinartz, W., \& Kumar, V. (2002). The mismanagement of customer loyalty. Harvard Business Review, 80(7), 86-95. https://pdfs.semanticscholar.org/5d77/592ce402dbc98d7de1007e07a14077 ae2eb4.pdf

Sakarya, S., Eckman, M., \& Hyllegard, K. H. (2007). Market selection for international expansion. International Marketing Review, 24(2), 208-238. https://doi.org/10.1108/02651330710741820

Sharma, P. (2011). Country-of-origin effects in developed vs. emerging markets: Exploring the contrasting roles of materialism and value-consciousness. Journal of International Business Studies, 42(2), 285-306. https://doi.org/10.1057/jibs.2010.16

Sommer, L. (2010). Internationalization processes of small and medium sized enterprises--A matter of attitude? Journal of International Entrepreneurship, 8(3), 288-317. https://doi.org/10.1007/s10843-010-0052-z

Sun, S. L., Peng, M. W., Ren, B., \& Yan, D. (2012). A comparative ownership advantage framework for cross-border M\&As: The rise of Chinese and Indian MNEs. Journal of World Business, 47(1), 4-16. https://doi.org/10.1016/j.jwb.2010.10.015

Sun, W., Price, J., \& Ding, Y. (2018). The longitudinal effects of internationalization on firm performance: The moderating role of marketing capability. Journal of Business Research, 95, 326-337. https://doi.org/10.1016/j.jbusres.2018.08.014.

Swoboda, B., Berg, B., \& Dabija, D. C. (2014). International transfer and perception of retail formats a comparison study in Germany and Romania. International Marketing Review, 31(2), 155-180. https://doi.org/10.1108/IMR-11-2012-0190

Szymanski, D. M., \& Henard, D. H. (2001). Customer satisfaction: A meta-analysis of the empirical evidence. Journal Academy of Marketing Science, 29(1), 16-35. http://dx.doi.org10.1177/0092070301291002

Teece, D. J., Pisano, G., \& Shuen, A. (1997). Dynamic capabilities and strategic management. Strategic Management Journal, 18(7), 509-533. https://doi.org/10.1002/(SICI)1097-0266

Van Nierop, J. E. M., Leeflanga, P. S. H., Teerling, M. L., \& Huizingh, K. R. E. (2011). The impact of the introduction and use of an informational website on offline customer buying behavior. Marketing, 28(2), 155-165. https://doi.org/10.1016/j.ijresmar.2011.02.002

Vida, I., Reardon, J., \& Fairhurst, A. (2000). Determinants of international retail involvement: The case of large US retail chains. Journal of International Marketing, 8(4), 37-60. https://doi.org/10.1509/jimk.8.4.37.19792

Welch, L. S., \& Luostarinen, R. (1988). Internationalization: Evolution of a concept. Journal of General Management, 14(2), 36-64. https://doi.org/10.1177\%2F030630708801400203

Westhead, P., Wright, M., \& Ucbasaran, D. (2001). The internationalization of new and small firms: A resource-based view. Journal of Business Venturing, 16(4), 333-358. https://doi.org/10.1016/S0883-9026(99)00063-4

Winter, S. (2003). Understanding dynamic capabilities. Strategic Management Journal, 24, 991-995. https://doi.org/10.1002/smj.318

Wood, S., Coe, N. M., \& Wrigley, N. (2014). Multi-scalar localization and capability transference: Exploring embeddedness in the Asian retail expansion of Tesco. Regional Studies, 50, 475-495. https://doi.org/10.1080/00343404.2014.926317

Wrigley, N., \& Currah, A. (2006). Globalizing retail and the 'new economy': The organizational challenge of 
e-commerce for the retail TNCs. Geoforum, 37(3), 340-351.

https://doi.org/10.1016/j.geoforum.2005.06.003

Yan, Z., Zhu, C. J., Fan, D., \& Kalfadellis, P. (2018). An institutional work view toward the internationalization of emerging market firms. Journal of World Business, 53(5), 682-694. https://doi.org/10.1016/j.jwb.2018.03.008

Zhu, K., \& Kenneth L. K. (2005). Post-adoption variations in usage and value of e-business by organizations: Cross-country evidence from the retail industry. Information Systems Research, 16(1), 61-84. https://doi.org/10.1287/isre.1050.0045

\section{Copyrights}

Copyright for this article is retained by the author(s), with first publication rights granted to the journal.

This is an open-access article distributed under the terms and conditions of the Creative Commons Attribution license (http://creativecommons.org/licenses/by/4.0/). 